WORKING PAPER NO. 12

Sept 1996

\title{
Assessing "Participation" in Forest Management: Workable Methods and Unworkable Assumptions
}

\author{
Carol J. Pierce Colfer and Reed L. Wadley
}

\begin{abstract}
Summary
This paper reports the results of a pre-test in West Kalimantan, Indonesia, of four methods designed to assess the level and nature of participation by local people in forest management quickly and easily. Two of the methods - the "Iterative Continuum Method" (ICM) and the participatory card sorting method - were deemed helpful. One method, the communication network analysis, was discarded in its current form. The final method, the researcher guide on the functions of participation, was felt in need of revision. Although the hypothesised firnctions of participation are not wrong, in our opinion, they reflect a way of looking at forest management which, we concluded, needs rethinking.In our discussion of the change needed we make use of Jordan's concept of "authoritative knowledge" and "social" or "cultural capital" (Berkes and Folke 1994; Ostrom 1994).We also suggest substituting "rights and obligations to manage the forest co-operatively " for "participation" in places like Danau Sentarum Wildlife Reserve (DSWR), where sustainable forest management is being assessed. Finally we conclude that, given the dynamism and complexity that characterise natural forests and their inhabitants, co-operation among all stakeholders in an ongoing dialogue is probably the only way that sustainable forest management can in fact occur.We urge researchers to continue the search for simple, inexpensive and reliable tools for assessing the issue we have called "participation in forest management."
\end{abstract}

\section{CENTER FOR INTERNATIONAL FORESTRY RESEARCH}

office address: Jalan Gunung Batu 5, Bogor 16001 Indonesia mailing address: P.O.Box 6596, JKPWB, Jakarta 10065 Indonesia tel.: +62(251) 34-3652 fax: +62(251) 32-6433

email: cifor@cgnet.com 


\section{The CGIAR System}

The Consultative Group on International Agricultural Research (CGIAR) is an informal association of 41 public and private sector donors that supports a network of sixteen international agricultural research institutes, CIFOR being the newest of these. The Group was established in 1971. The CGIAR Centers are part of a global agricultural research system which endeavor to apply international scientific capacity to solution of the problems of the world's disadvantaged people.

\section{CIFOR}

CIFOR was established under the CGIAR system in response to global concerns about the social, environmental and economic consequences of loss and degradation of forests. It operates through a series of highly decentralized partnerships with key institutions and/or individuals throughout the developing and industrialized worlds. The nature and duration of these partnerships are determined by the specific research problems being addressed. This research agenda is under constant review and is subject to change as the partners recognize new opportunities and problems. 


\title{
Assessing "Participation" in Forest Management: Workable Methods and Unworkable Assumptions
}

\author{
Carol J. Pierce Colfer and Reed L. Wadley ${ }^{1}$
}

\begin{abstract}
Summary
This paper reports the results of a pre-test in West Kalimantan, Indonesia, of four methods designed to assess the level and nature of participation by local people in forest management quickly and easily. Two of the methods the "Iterative Continuum Method" (ICM) and the participatory card sorting method - were deemed helpful. One method, the communication network analysis, was discarded in its current form. The final method, the researcher guide on the functions of participation, was felt in need of revision.Although the hypothesised functions of participation are not wrong, in our opinion, they reflect a way of looking at forest management which, we concluded, needs rethinking. In our discussion of the change needed, we make use of Jordan's concept of "authoritative knowledge" and "social" or "cultural capital" (Berkes and Folke 1994; Ostrom 1994).We also suggest substituting "rights and obligations to manage the forest co-operatively" for "participation" in places like Danau Sentarum Wildlife Reserve (DSWR), where sustainable forest management is being assessed. Finally we conclude that, given the dynamism and complexity that characterise natural forests and their inhabitants, co-operation among all stakeholders in an ongoing dialogue is probably the only way that sustainable forest management can in fact occur We urge researchers to continue the search for simple, inexpensive and reliable tools for assessing the issue we have called "participation in forest management."
\end{abstract}

\section{Introduction}

In the course of an ongoing project to test criteria and indicators for sustainable forest management, people's participation in forest management was identified as an important criterion for sustainable forest management $^{2}$. As we examined our first phase results, we identified an important shortcoming. Although there was general agreement that participation was an important issue, we could not specify, to our satisfaction, the relevant causal links between sustainable, commercial forest management on the one hand, and the participatory behaviour and needs of the people most closely involved on the other.

We found a variety of processes in the field. Increased participation provided forest people with a sense of ownership, or a defined "stake", in forest management. It provided managers with useful knowledge about local forest use and management strategies, as well as a means for conflict resolution and empowerment. In other contexts, increased participation seemed to involve increased conflict. Such conflict might have positive outcomes in some cases, negative ones in others, from a sustainability point of view. The concept of participation in commercial forest manage- ment seemed to beg further analysis, improved definition, and improved methods to reliably assess it on the ground, in a short period of time.

In response to this perceived shortcoming, we planned a series of pre-tests (two) and tests (three) designed to a) clarify the causal links between sustainable forest management and participation ${ }^{3}$, and $b$ ) develop methods by which participation can be assessed quickly, easily and reliably in the field. This paper reports the results of our first pre-test. We discuss our findings from the four methods tested, and argue that the concept of "participation" as commonly used in natural resource management contexts may rest on an inappropriate assumption - at least in the West Kalimantan study site.

\section{Study Site ${ }^{4}$}

We selected the area in and around Danau Sentarum Wildlife Reserve (DSWR) in West Kalimantan, Indonesia, to conduct our pre-test. DSWR was originally gazetted as an 80,000 ha reserve because of its ecological uniqueness. It is an area of seasonally flooded, black-water lakes, in the remote interior of Borneo near the border with Malaysia. During the past 
couple of years considerable progress has been made toward expanding the borders to include the hills to the east of the reserve (now officially under the management of timber concessionaires). This would result in a reserve of 125,000 ha.

We selected this area because a) we had 45 (combined) months of field experience there (1992-94), with considerable associated qualitative and quantitative data, and b) there was an ongoing project at DSWR with whom we could co-operate. This project had over 130 reports on a variety of natural resource management topics, compiled over the previous four years, from which we could draw. The explicit approach of the Conservation Project was to work toward comanagement of the reserve, and significant efforts had been devoted to this goal.

There were also qualities about the area itself which contributed to its appropriateness: the wildlife reserve was surrounded by timber concessions; there were two ethnic groups with quite different patterns of resource use and, we thought, levels of participation in forest management; the existence of indigenous, conservation and production forest management seemed also to offer interesting possibilities for comparison.

\section{Methods Pre-Tested}

Our pre-test took place in June and July 1996, and involved two primary researchers (Colfer and Wadley), with other team members recruited locally 5 . We focused on four small communities ${ }^{6}$ : Danau Seluang and Ng. Kedebu' which were Melayu communities; and Wong Garai and Bemban were Iban communities. Another Iban community, Kelayang, was added later after revising the methods significantly. The Conservation Project had worked extensively with $\mathrm{Ng}$. Kedebu', Bemban and Kelayang; and hardly at all with Danau Seluang and Wong Garai. Ng. Kedebu', located near the Conservation Project Field Center, has had involvement in the project since its inception in 1992 (providing guides, research assistants, temporary accommodation, study sites, etc.). Kelayang was recently included in an expansion of the reserve boundaries. Both Kelayang and Bemban were currently involved in the Conservation Project's income-generating efforts (basket weaving).

In selecting appropriate methods, we considered several factors. We felt that a combination of qualitative and quantitative methods would be preferable to either one alone. Ultimately four methods designed to assess participation were tested: the "Iterative Continuum Method" (ICM), a participatory card sorting method, a communication network analysis instrument and a researcher guide. The methods were translated into Indonesian, Melayu, and Iban as appropriate.

- The $I C M$ involved daily estimates by the primary researchers (and occasionally similar estimates from local people) about the placement of the study sites on a continuum from "no significant participation by local people" to "very significant participation by local people" in forest management. The process of making these daily records was designed a) to record a growing qualitative understanding of the situation, and b) to provide a structure for recording examples of causal links between people's participation and sustainable forest management. Such examples were meant to serve as a source of evidence about the level of participation and its effects (Appendix A shows the form, as it was revised in the field).

- The participatory card sorting method was quite loosely defined at the outset. Six colours were available for cards, and the initial plan was to have people order the stakeholders (written on the cards) according to their importance in forest management and their frequency of interaction with that stakeholder. An attempt would be made to get a variety of respondents (by age, sex, occupation, wealth, etc.). Group and individual interviews were anticipated (Appendix B).

- The communication network analysis required a survey instrument, which asked the respondent first to name the people with whom he or she most often discussed forest use. Respondents were then asked to list names of people from the timber concessions, from the Conservation Project and, finally, others they considered important in forest management. Most adults in each community were anticipated as respondents (see Appendix C).

- A researcher guide was prepared, for use by the primary researchers (with use by others, as deemed appropriate), which focused on four functions of participation, proposed by Colfer. The four functions proposed included: reducing non-compliance of various stakeholders with regulations by local monitoring; reducing conflict about forest management or converting it to mutual accommodation; contributing indigenous knowledge of forest management; and controlling the speed and direction of social change. The purpose of the researcher guide was to a) examine the functions in a field context, and b) remind us of potentially relevant issues (see Appendix D). 


\section{Results of the Pre-Test}

Our results include several components. First, we document the experience and skills of our local collaborators, since future teams can operate more economically if they can make use of local people in their studies. Second, we report our experience with the four methods we tried, including problems, changes and costs associated with the methods, as far as possible.

\section{Locally Recruited Team Members}

Recognising the probability of various levels of expertise in future teams assessing sustainability, with lower levels of expertise and local knowledge than we ourselves have, we wanted the methods to be easy to understand and use. We therefore tried them ourselves, and involved other people with varying kinds and levels of training, in the trials. Our locally recruited assistants included ten men and women, ranging in age from 13 to about 50, with educational levels from sixth grade to some postsecondary training, plus one foreign doctoral candidate who helped us in one community. Of the ten paid assistants, only one proved unable to do the work, with minimal supervision, and that may have been because he was trying to interview people using the rejected Communication Network Analysis instrument.

\section{Experience with the Four Methods}

The four methods will be presented in reverse order of success. The first two, not having been particularly useful in this context, are dealt with briefly; the second two, in much more detail. We do not, incidentally, consider these methods to be sufficient for an adequate assessment of "participation in forest management"; rather they are intended as a first step in that direction.

\section{Communication Network Analysis Instrument}

This instrument (Appendix C) was based on the supposition that communication is a prerequisite for participation in the forest management context. We hoped to determine the main actors in forest management, and the intensity and nature of interaction between villagers and these managers. All interviewers (local and international) found the communication network analysis instrument difficult to use. Respondents did not relate well to the abstract idea of "forest use" or "forest management ${ }^{8 "}$. None of the interviewers had confidence in the results from this survey. It also became clear that it would be quite difficult to analyse, requiring considerable additional investigation to determine who they regularly spoke with about forest use within and beyond people in their own households and communities. This method was abandoned, in its current form, after testing in Ng. Kedebu' and Wong Garai.

\section{Researcher Guide on the four functions of participation}

The Researcher Guide (Appendix D) was based on the four functions (listed above) that Colfer hypothesised might be critical functions of participation in sustainable forest management. In the DSWR context, since management appeared to be largely in the hands of local people, the answers to most questions were "yes, they were participating," even though they were not participating in management that was recognised externally (particularly in commercial timber management - the context for which the questions were initially formulated). This observation or conclusion prompted a thorough review of our assumptions. In our previous field tests (1994-95), we focused on a formal, forest management unit (FMU) and, from the social perspective, tried to assess the conditions of the people within that FMU. How to involve local people in these activities in a mutually beneficial way had been the question in the minds of the field teams. It remains an important question. However, it assumes the priority of the activities of the timber manager.

In the DSWR context, where there were at least four kinds of management operating (including those of the Conservation Project, commercial timber companies, Iban villagers and Melayu villagers), the question of participation in which system became important. Phrasing the question as we had earlier (how to involve local people in FMU management) ignores the many places where local people's management has more effect on local forests than does external management. However inadvertently, it also reinforces the power of the timber manager or government official vis-a-vis local people. This question is discussed in greater detail in the next section of this paper.

\section{Participatory Card Sorting Method}

The participatory card sorting method, like the communication network analysis, was selected as a method based on the idea that a prerequisite for effective participation was regular communication. However, the initial plan was vague. The $\mathrm{Ng}$. Kedebu' and Wong Garai team members all conducted a number of interviews using the participatory card sorting method. Again local people had difficulty with the abstract notion of "forest management" or "forest use."

In response to these problems, Colfer refined it. This new form (see Appendix B) specified six relevant stakeholders: the local community, other communities, the government, the timber companies, the conservation 
project and traders. Each stakeholder was listed on a different coloured card ${ }^{9}$. The form also asked four questions - each a concrete example of a component of forest management ${ }^{10}$. The questions pertained to 1) seeking information about fish, 2) looking for rattan, 3) looking for valuable wood, and 4) problems between timber concessionaires and other stakeholders. These questions were designed to reflect local forest management by identifying who had knowledge, who controlled and made use of resources, and who was involved in conflict resolution. We anticipated a sample of 12 to 15 respondents in each area, evenly divided (if possible) by gender, and representing whatever diversity we found. Respondents could be individuals or groups.

People were asked first to rank the stakeholders by "importance ${ }^{11}$ " for each of these four topics (column A). It was necessary to rank all six stakeholders (for analysis purposes), even if their role was quite unimportant. The people were then asked to allocate 100 points among these stakeholders, depending on frequency of interaction, for each topic (column B). Zero was an acceptable value for frequency of interaction.

Researchers and local people found this instrument much more useful. People could answer the questions more easily and researchers had more confidence in the answers. As with most surveys, there was some variation in people's comfort levels. Most people found it fairly easy, and many appeared to enjoy it. One employee in one of the timber companies involved in a dispute with a nearby community refused to do the sort; and some of her co-workers mysteriously disappeared before we could ask them. Two fisheries officials (also involved in a dispute with local communities) and several Iban residents of Bemban were obviously frightened by it. Colfer went alone to Bemban. Although she had worked in the community and had good rapport with them, the alien nature of form-completion combined with her inability to speak sufficient Iban to explain the purposes of the form satisfactorily frightened would-be respondents. She abandoned the attempt after four tries. An obvious conclusion is that the ability to communicate well is a prerequisite for using this form, particularly in remote areas.

The analysis of the resulting data is quite simple. In a short period of time Ida Marlia was trained (beginning with no experience using Excel) to do the analyses. The results are a simple average of ranking by importance and by frequency of interaction - both important issues in assessing people's involvement in managing forests. Disaggregating the responses by gender, occupation, location or other dimension is also easy.

The most interesting similarity among the groups was the importance assigned to the local community.
Averages ranged from 1.00 to 1.93 , whether disaggregated by gender, occupation or location (See Tables 110 in Appendix B, for various ways the data sets were analysed). In all cases the local community was ranked the-most important and in all but one (Kelayang, Table 10) it received the highest average score in frequency of interaction. Interestingly, Kelayang is the community that is within the timber company which is partially owned by Iban from a nearby area (P.T. Panggau Libau), and they reported interacting most frequently with the timber company on forest management issues, with the community a close second. This makes an interesting contrast with the north-west of DSWR, also within a timber concession (P.T. Militer), but one wholly owned and operated by outsiders. There, the concessionaire is ranked fourth in importance (Table 3); and shares second place $(11 \%)$ with "other communities" and "government" in frequency of interaction, far below the mean for interaction with "community" (49\%; Table 8).

The Conservation Project rose to third place in terms of mean order of importance and fourth place for frequency of interaction, in Ng. Kedebu' (Tables 2 and 7) where the project has been active for four years, from sixth place in Danau Seluang (Tables 1 and 6), a community which has not yet been involved with the project. This suggests both less communication with the project than its leaders might wish for $\mathrm{Ng}$. Kedebu' and an accurate depiction of the noncommunication that has existed between the project and Danau Seluang. As with the Kelayang example above, these data show the pre-eminence of local communities in local forest management.

Most of our card sorting was done in local communities, and one could argue that local communities perceive their own importance to be greater than would other stakeholders in the area. However, the card sorting data from outsiders do not confirm this view. In Tables 3 and 8, the P.T. Militer Log Camp responses; and in Tables 4 and 9, the Business and Government responses, reflect similarly high ranking of communities by outsiders, both in terms of importance and in terms of interaction $^{12}$. This provides clear evidence of the near unanimity with which local people's management is recognised as pre-eminent in the area - despite governmental perceptions to the contrary (in the form of timber concessions held by outsiders and the conservation activities under way in the wildlife reserve). Conducting the card sorting exercise with more distant stakeholders would be of interest, but was outside the scope of our pre-test. Differences in men's and women's ordering (Tables 1,2,5 and 6,7,10) both for importance and for frequency of interaction appear to be minimal. 
In another location different stakeholders and different, locally relevant questions which together can serve as a proxy for "forest management" or "forest use" can easily be substituted for those Colfer chose for DSWR. In selecting these proxies, it is important not to neglect activities which do not have high visibility in the world of commercial timber management (such as women's use of medicinal plants or forest foods, or a particular ethnic group's collection of NTFP from various stages of secondary forest). In our own future use of the method, we will revise the questions to reflect more clearly four components of forest management that we consider important and linked to participation: knowledge, regulation, conjlict resolution and sanctions. Others may emerge as important in future tests. In this way, we hope to capture some of the functions of participation hypothesised in the Researcher Guide (described above).

The cost of conducting this survey is minimal. The revised card sorting technique was tried in five communities (Ng. Kedebu', Danau Seluang, Bemban, Pulau Duri' and Kelayang) and in several other contexts (timber base camps, a sawmill, government offices, among traders, etc.). In each community, 12 - 15 forms were completed, roughly evenly divided among men and women (some in mixed groups). Including waiting and travel time, the actual conduct of the survey took about two days. The costs varied by community (including wages, subsistence and transport for local data gatherers) from about \$25-\$50. This does not include the cost of "expert" time, but presumably methods such as this would be part of a larger effort which would vary in length, from a few days to a month. Very little of the expert's time is required in supervision for this method.

The cost of data entry and subsequent analysis is also minimal. The data from one community ( 15 forms) can be entered and analysed in a couple of hours by a technician, to show who is considered most important locally in forest management and who is involved on a regular basis (frequency of interaction) with such issues. Conducting the exercise in several contexts is important, to reflect local variation in perceptions and practice.

Our experience with this method was positive, in terms of ease of data collection and analysis, apparent reliability and cost.

\section{"Iterative Continuum Method", or ICM}

The ICM (Appendix A), again, involved daily entries by the primary researchers, who specified their judgement, as of that day, regarding the placement of the area on a participation continuum (from "significant to "insignificant"), and the direction of change. The form was used by the primary researchers on a daily basis, and with several local people and the research assistants, once ${ }^{13}$.
There was space on the form for cases, stories, evidence that people were or were not participating in forest management. The input of local people and the assistants was useful in adding to the sum total of information coming in, but their perceptions were constrained by their purely local experience.

Both Colfer and Wadley had problems with the initial participation continuum. The day-to-day participation of local people in the management of their environment was obvious, and their lack of involvement in timber company management on a day-to-day basis was equally obvious. We therefore reworded the continuum to say "recognised, functioning rights to manage forest resources co-operatively." With this wording, DSWR was placed at " 5 " on a 0-10 scale. Our judgement is that the prognosis for the future, in the absence of significant change, points toward fewer rights and obligations of local people, as national-level penetration increases (though this is not necessarily consistent with their perceptions).

We found the modified ICM useful in making certain that important events or interactions between people and forests were recorded for later consideration. Perhaps most important was the growing conviction, as the fieldwork progressed, that the continuum needed "anchoring." This prompted the development of a (very) preliminary series of (global) steps toward sustainability on this continuum. These steps will be modified further, consistent with future testing in other locations. For use by less-experienced researchers or teams with less international experience, the anchoring will have to be improved over its current state (see Appendix A).

In terms of expense, this method requires a small amount of time, but a high degree of experience and training. With improvements in the anchoring "steps" and training, the method could be used by less-experienced assessors. In terms of expense, Colfer spent 9 hours, over the course of 17 days, filling in the forms in six communities (including continua on two other topics). Wadley spent 1.5 hours over 7 days in Wong Garai, and Harwell spent about an hour over a 4-day period in Kelayang.

\section{Methodological Conclusions}

Of the four methods tested, one was rejected as too complex and expensive (communication network analysis), one was considered inappropriate for the particular local context, though retained as perhaps more relevant in other areas (the researcher guide on participation), one was revised and used quite productively for gaining a quantified assessment pertaining to participation (the card sorting method), and one was also revised to systematise a growing qualitative under 
standing of issues pertaining to co-operative management of resources (ICM).

Perhaps more importantly, this research identified an important need to rethink our use of the concept of participation in forest management ${ }^{14}$.

\section{An Unworkable Assumption, or Participation in What?}

In recent years, a rather sizeable literature has emerged on participation - one that these authors have welcomed and read with interest. Indeed, it was with this literature in mind that we prepared for the West Kalimantan pre-test. We were quite convinced of the importance of people's participation in forest management.

An appealing World Bank definition (1994: 75) is "Participation is a process through which stakeholders influence and share control over development initiatives and the decisions and resources which affect them." Pretty (in Pimbert and Pretty 1995) provides a typology of participation, including passive participation ("where people are 'involved' merely by being told what is to happen"), participation in information giving, participation by consultation, participation for material incentives, functional participation, interactive participation, and finally self-mobilisation. The kind of participation we have envisioned, in a sustainably managed forest, seems closest to Pretty's last two:

- "Interactive participation," which is "People participat[ing] in joint analysis, which leads to action plans and the formation of new local groups or the strengthening of existing ones. It tends to involve inter-disciplinary methodologies that seek multiple perspectives and make use of systematic and structured learning processes. These groups take control over local decisions, and so people have a stake in maintaining structure or practices." (cf. the attempt by the Conservation Project to work co-operatively with local communities and build on their management systems.)

- "Self-mobilization", which is "People participat[ing] by taking initiatives independent of external institutions to change systems. Such self-initiated mobilization and collective action may or may not challenge existing inequitable distributions of wealth and power." (p. 26) (cf. the self-mobilisation described in the two boxes.)

As we began conducting the Kalimantan pre-test, we realised that we were operating under an unworkable assumption: We found (and at first unconsciously shared) an assumption that the local people would somehow be brought into the management system of the government or of the timber concessionaire (or both; or cf. Songan's (1993) analysis of Iban "participation" in a Malaysian agricultural scheme). We illustrate this assumption with two recent quotes. Coakes (1996), for instance $^{15}$, outlines "how [community] stakeholders can be actively involved in the process of forest management." Carter et al. (1995) ask if participation "provide[s local communities] with the knowledge they need to take decisions and become managers...?" These questions probably make a lot of sense in many environments but, in West Kalimantan (and we suspect other areas as well), it seemed that the local people were actually the stakeholders most actively involved in the process of forest management, and that they already were (under-recognised) managers of the forest.

We also found that much of the literature on participation focuses on projects (e.g., BCN 1996; Isham et al. 1995; Songan 1993). The project context is almost by definition limited in time, whereas sustainable forest management assumes and requires a much longer time horizon. In the West Kalimantan context, we found it necessary to think about participation in the Conservation Project in quite a different light from participation in sustainable forest management in general. Some communities were quite earnestly involved in incomegenerating activities initiated through the project, and the project had been quite successful in trying to build on traditional management. But looking at people's participation in sustainable forest management required attention to the activities of timber concessionaires and shifting cultivators; and we had to ask who was actually doing what that had an impact on the sustainability of forests and of people's ways of life within the forest ${ }^{16}$.

Looking at the forests in the area of Danau Sentarum (both within and outside the Wildlife Reserve), we see at least three distinct systems of management - each with a completely different approach. It is hard to deny that the Melayu fishing people have a complex resource management system (Malvestuto 1989; Bailey et al. 1990; Bailey and Zerner 1992; Colfer et al. 1996; Dudley 1996b; Wickham 1996; among others); similarly the Iban swiddeners (Dudley and Colfer 1993; Wadley 1996; Wadley et al., 1997). Both ethnic groups have areas with defined borders, sets of regulations and sanctions and mechanisms for applying those sanctions when their regulations are not followed (see Appendix F). Melayu management is centred primarily on fisheries, though they also manage their rattan and wood supplies (cf. Peters 1993, 1994). Iban management focuses on forest resources as part of a complex system of agroforestry involving, in part, the cycling of longfallow forest for swiddening, the cultivation of forest fruits and the preservation of both large and small tree stands for multiple use. The operation of these systems - though imperfect - is visible on a daily basis. 


\section{DSWR Fisheries Management in Action}

A jermal padat is a large, funnel net which is used at the mouths of small rivers or along the edges of large ones. At the business end of the net, the mesh is almost as fine as window screening, and huge amounts of fish are caught in these nets (approximately $10 \%$ of the total annual catch, which is estimated at around 10,000 tonnes, Dudley 1996a). There are 200-300 jermals in the DSWR area (Dudley 1996b).

In 1992, there was considerable grumbling at DSWR about the jermal, from fishers as well as officials, all of whom felt the nets were catching too many fish, both from the standpoint of the fishery's sustainability and from the standpoint of equity, since only the wealthy could afford a jermal (see also Giesen 1987). We were told that use of jermal had in fact been declared illegal and was being phased out, but that the Fisheries Department was going slowly with implementation so as to minimise loss to current jermal owners. In 1996, the same complaints could be heard.

Nothing seemed to have changed. Meanwhile the indigenous fisheries management of local people within the reserve was in the process of being strengthened and supported by the Conservation Project. The project had organised intra- and inter-village meetings, documented existing local regulations, mapped traditional management areas, and it was trying to secure letters of authority from the Kabupaten (or Regency) to grant fishers more official power in implementing their regulations. These efforts were motivated partly by a recurring management dilemma in the lakes area. Those managing do not have the authority to manage; and those in authority are not only not managing, they are in some cases interfering with effective management.

In Danau Seluang, we learned of a representative conflict which captures this situation. Two nearby communities were situated on a common lake. One of the communities (Tayak) had regulations which they enforced against the use of jermal padat in their territory; the other (Dayong) allowed use of jermal padat. Tayak complained to the authorities, citing prohibition on use of the nets from the governor, the regent, the county officials, as well as a treaty signed by all DSWR communities and many surrounding it in 1994, promising not to use poison, electric fishing, or jermal padat in the lakes area.

A meeting was held in Tayak in June, which was attended by head fishermen from five fishing communities, heads of five villages, county officials, and representatives of Fisheries, the Military, and the Police At this meeting, although everyone agreed that the nets were a) undesirable from fisheries and equity perspectives, and b) prohibited by a variety of supposed managers, no conclusion could be reached. Why? Because the people of Dayong had a written permit from the Fisheries Department, for which they had paid Rp. 30,000, to use jermal padat.

When the county commissioner was asked why no conclusion could be reached, he said that the government didn't have a legal leg to stand on, since another Government department had given permission and the jermal owner had paid for a licence. When the Fisheries Department personnel were asked the same question, they looked uneasy, saying that this was an inter-community boundary dispute, over which the Fisheries Department had no authority.

Local people, trying to manage local resources in a responsible fashion, cannot rely on the institutions formally charged with management for support. At the same time formal government management is ineffective, due to inadequate staff numbers, low staff qualifications and motivation, under-budgeting, and all the myriad problems that plague third-world bureaucracies. 
A second system of management derives from the commercial timber industry in concert with the Indonesian government. Timber concessions have been given to a number of companies to harvest timber in areas all around the reserve. These companies (or in some cases, their predecessors) have been operating for roughly two decades. Again, borders are defined, there are regulations, theoretically there are sanctions and mechanisms for dealing with infractions. All of these management components, however, differ significantly from those of local people and, with the exception of harvesting and log transport, are much less obvious than is community management.

The beginning of the Conservation Project in the Lakes area in 1992 has brought a third system of management. This project attempts to manage the resources co-operatively with local people. It is trying to strengthen the existing management by local people as a means of attaining the sustainable management and conservation of a unique biome. The Danau Sentarum Wildlife Reserve has still another set of borders, with somewhat different regulations, sanctions and mechanisms for conflict resolution. One could in fact identify still other systems of management with intended effects in this area (such as that claimed by the Fisheries Department).

Who, then, is managing the forest? The results from our study suggest that, in the DSWR area, the local people are almost unanimously perceived to be the most important actors in forest management (see Tables 1 - 10). As noted before, not only villagers from both ethnic groups and various villages, but also government officials, traders and timber company employees generally share the perception that local people are the most important stakeholders in forest management and report that they interact most with local people on such issues.

It is probable that the perceived importance of these people in forest management would decline as distance from the site increased (such that officials in Pontianak, and even more so in Jakarta, would consider local people to be less significant). Yet day-to-day management obviously occurs at the local level which one can phrase as a community or as a forest management unit, depending on one's orientation system.

In fact, the traditional local system is the only management that seems fully operational. Although the concessionaires have regulations which they are bound by contract to follow, it appears that many of these regulations exist largely on paper, with little or no on-the-ground monitoring by the government. When asked, for instance, what regulations the conces- sionaires had to follow, one of two local forest agents listed three kinds of tax the companies are required to pay. When Colfer clarified her intent by asking about regulations like minimum size of tree to be cut or road building requirements, the forestry agent looked blank. After thinking a minute, he acknowledged that such regulations did exist and were monitored by the Forestry Department. However, it took considerably more thinking to decide that it must be the Forestry Department in Pontianak that did this. Similarly the Conservation Project, in its laudable attempt to work co-operatively with local people, does not enforce the regulations of the Forest Conservation and Nature Protection Agency (PHPA). Indeed, if it were to do so, it would have to evict several thousand current residents of the Wildlife Reserve!

What are the implications of this kind of situation for "people's participation in forest management"? These people are involved in forest management already. The four functions that participation in forest management were hypothesised to fulfil (see page 2 or Appendix D) are indeed operative, but within their own system, not as their activities pertain to the other systems. One might more reasonably ponder how the timber concessionaire could more meaningfully "participate" in the local people's management - if sustainable forest management is our goal.

Before proceeding to a discussion of some concepts we feel have a bearing on how we look at local people's participation in what might be alien systems of management, we would like to mention some subsidiary findings pertaining to conflict (another issue considered important in all CIFOR's 1994-95 field tests). The initial tendency of these teams (and ourselves as well) was to consider conflict to be a negative occurrence, with potentially adverse effects on sustainable forest management. We saw the extremes of war as a natural progression in a continuum of levels of conflict, which would ultimately destroy both the forest and the lives of the people in it.

However, in West Kalimantan we found that disputes ${ }^{17}$ appeared to have salutary effects on the well-being of local people. In the past, the inherent conflicts among the three major management systems operating in and around DSWR have been avoidable (consistent with Indonesians' common cultural preference for overt harmony) for the following reasons:

- the area in question was sparsely populated, and the concessionaires could cut a sufficient volume of timber in comparatively distant areas.

- the availability of other areas to the concessionaires allowed them to accede to community wishes in many cases of disagreement. 


\section{Preserving Traditional Rights}

In 1989, the people of Wong Garai became alarmed when they learned that P. T. Militer had built one kilometre of logging road into their territory on Bukit Pelawan and that surveys were being done for eventual cutting. The forest there was mainly old growth that had not been farmed in the past, because of the poor soil on the mountain. The people were now concerned about preserving the forest for their long-term use. They had seen other longhouse communities in the area whose lands had been logged having no places to obtain building materials, no places to hunt and gather forest products, and fouled water sources with declining fish populations.

The Wong Garai leaders notified the district officer and told the local logging manager that they would not allow any cutting within their territory. They also marked trees with red paint along the territory boundary. P. T. Militer offered the headman (kepala desa) Rp. 7,000,000 (\$3,500 at the approximate 1989 exchange rate of US\$1 = Rp. 2,000) if he would allow the logging to proceed, but he declined. Fortunately one of Wong Garai' s own was currently serving a term as legislator in the Regency legislature (Dewan Perwakilan Rakyat) in Putussibau. With his help and influence. Wong Garai secured their forest from logging. The Bupati (regency head) agreed to support them and issued an order protecting the forest. In the same letter, he also gave official support to what apparently was a traditional Iban practice, prohibiting the farming of mountain peaks, in order to prevent erosion and the drying up of water sources.

This success set a precedent for the community. Wong Garai also has an area of old-growth lowland swamp forest. Some of it had been converted over the past century into swamp rice fields, but a large area still remains. The community has been successful in preserving it from other longhouses that have tried to establish claims on the land (Wadley 1996), and it is intent on preventing any logging as well.

- the activities of outsiders included some minor benefits (such as improved access, a small amount of employment, increased exposure to the outside world).

- there is an ethic of hospitality in Borneo, perhaps deriving from the historical sparseness of population, which welcomes newcomers (cf. Peluso's "ethic of access" 1994).

However, recently, the available forest has shrunk. The timber companies are moving into areas the local people want to protect for their own use and that of their children. So far the government and the concessionaires have not found it expedient to disregard community sentiment completely - perhaps in partial local recognition of the duties and responsibilities of management that fall to local people while many of the benefits from the forest accrue to outsiders. But the concessionaires and the Forestry Department, particularly at higher levels in the bureaucracy, consider the concessionaires' claims to be pre-eminent. There is considerable scope for serious disputes - with detrimental effects on local people - in this situation, particularly given that the basic laws regarding traditional rights to land are subject to varying interpretations (see Colfer, with Dudley 1993: 75-80). The timber companies also have better access to information, to financial resources, and to the more powerful regional and national decision makers than do local people.

\section{"Authoritative Knowledge:" An Explanation for Our Unworkable Assumptions about Participation}

The crux of the problem, in our view, can be summed up in a concept originally put forth by Brigitte Jordan with regard, strangely enough, to childbirth (see Jordan with Davis-Floyd 1993; Jordan, in press; Davis-Floyd and Sargent, in press; etc.) ${ }^{18}$. Jordan (1991) has also applied this concept in the context of US air traffic control. Because readers of this article are unlikely to be familiar with Jordan's work, we quote her at some length: 
...for any particular domain [such as forest management] several knowledge systems exist, some of which, by consensus, come to carry more weight than others, either because they explain the state of the world better for the purposes at hand (efficacy) or because they are associated with a stronger power base (structural superiority) ${ }^{19}$. A consequence of the legitimation of one kind of knowing as authoritative is the devaluation, often the dismissal, of all other kinds of knowing. Those who espouse alternative knowledge systems then tend to be seen as backward, ignorant, or naive trouble makers. Whatever they might think they have to say about the issues up for negotiation is judged irrelevant, unfounded, and not to the point...The constitution of authoritative knowledge is an ongoing social process that both builds and reflects power relationships within a community of practice...It does this in such a way that all participants come to see the current social order as a natural order, i.e., the way things (obviously) are. The devaluation of non-authoritative knowledge systems is a general mechanism by which hierarchical knowledge structures are generated and displayed. (in press, p. 2)

The power of authoritative knowledge is not that it is correct but that it counts. [Jordan's italics, in press, p. 4]

By authoritative knowledge, I specifically do not mean the knowledge of people in authority positions....Authoritative knowledge is an interactionally grounded notion. (in press, pp. 4-5)

We are suggesting that indigenous knowledge and management systems of local people in DSWR - and many other rural forested areas of the world - are ignored, indeed not even perceived, because they are not considered by the more powerful to constitute "authoritative knowledge" (see also Chambers 1994; Long and Villareal 1994; Salas 1994; or more philosophically, the writings of Foucault, particularly on the link between knowledge and power). The global treatment of traditional vis-à-vis "modern" forest management is a comparable situation. The existence of and general compliance with locally defined regulations which marks the traditional management system in Danau Sentarum, for instance, is in marked contrast to the apparent irrelevance of "modern" Forest Department regulations in the surrounding $\operatorname{area}^{20}$.
Non-compliance with regulations by offtcially sanctioned (i.e., "modern") forest managers is a recurrent and chronic problem in tropical forest. The global evidence for the sustainability of many traditional systems consistently mounts (e.g., Clay 1988; Fortmann and Bruce 1988; Redford and Padoch 1992; Colfer et al. in press), alongside the increasing evidence of non-sustainable practices and policies within the modern sector (e.g., Head and Heinzman 1990; Barbier et al. 1994; or Ascher 1993, on Indonesia specifically).

The irony is that continued access to the resources by stakeholders unconcerned with sustainability issues effectively undercuts the strength of the traditional systems (see, e.g., Peluso 1994). When other stakeholders are free to harvest local resources at will, outside the control of either the indigenous or the "modern" system, convincing local people to moderate their own use becomes much more difficult. Traditional regulations lose their force. Why try to conserve a local resource when the unsustainable harvesting by others cannot be controlled?

\section{When Others Don't Follow the Rules....}

The people of Danau Seluang told of an incident in 1982-83. An Iban community, living upriver from Danau Seluang, used tuba, an illegal fish poison, in a river that drained into the nearby lake. Eleven times the people of Danau Seluang caught them, and reported the incident to the Fisheries Department. In each case, nothing was done. On the twelfth time, the people of Danau Seluang decided to use tuba themselves, as a form of protest. Although 250 individuals from the community were taken to jail, they succeeded in making their point, and were soon let out. The use of tuba by the Iban was not a problem for some time after that. 
The suggestion here is definitely not that traditional systems are the be-all and end-all of sustainable management. They quite obviously have their failings as well particularly in situations where change is occurring rapidly. However, if we agree that there is sufficient evidence that people's participation in forest management is important, then we must consider the possibility of turning our current assumptions on their heads.

The concept of authoritative knowledge in this context is useful in explaining why the management of forests continues to be perceived as rightfully in the hands of the modern sector - in the face of mounting evidence of biological, human and economic unsustainability within the modern system. The prestige of science, modernity and the west is wrapped up in "modern forest management". This can be seen in operation from the highest level, where third-world countries compete to show their compliance with the wishes and cultural preferences of their previous "colonial masters" to the forest ranger whose personal prestige depends on village-level acceptance of "modern forestry" (Umans 1995; or for this issue more generally, Colfer 1983). Ultimately recognition of the legitimacy of indigenous management may be a prerequisite for sustainable forest management in areas like West Kalimantan.

The ideas of social or cultural capital have been proposed by several authors. Ostrom (1994) proposes "social capital" as a relevant feature in considering the relative importance of indigenous vis-á-vis "modern" systems. Following Coleman (1988) and Putnam (1993), she defines social capital as:

...the shared knowledge, understanding and patterns of interaction that a group of individuals brings to any productive activity.....[It] is created when individuals learn to trust one another so that they are able to make credible commitments and rely on generalized forms of reciprocity rather than on narrow sequences of specific quid pro quo relationships. (Orstom 1994: 20).

Berkes and Folke (1994; also Barbier et al. 1994) discuss a similar concept, "cultural capital".

These concepts in fact reflect the existence of human resources which can and should be used in resource management. In the DSWR context, although there may be a governmental "will" to manage the forest effectively, to date there has not been the means (due to problems like inadequate staff numbers, poorly trained staff, small budgets, logistical problems that interfere with supervision and monitoring of concessionaires, etc.). Local social and cultural capital provide that means to some extent already. Recognition and strengthening of that capital may be the most valuable role for outsiders, like government and private industry, in moving toward more sustainable forest management.

Jordan has found some contexts (like the rural Mexican birth environment or the air traffic control context) in which input from various actors comes together in improved analysis of situations and solutions to problems that emerge. She concludes that:

In some groups, differing kinds of knowledge come into conflict, in others, they become a resource for constructing a joint way of seeing the world, a way of defining what shall count as authoritative knowledge. (in press, p. 6)

Within the international forestry context, and this is certainly true of the DSWR area, dramatic changes are occurring. The traditional systems that were sustainable under previous conditions are under great stress; and in many cases the "modern" approaches are devastating to tropical forests and the species within them.

Neither approach, alone, is or will be adequate to the changing circumstance. Nor is it likely that a "final solution" is possible ${ }^{21}$.

Forest management, intimately connected with the needs and wishes of human beings, must inevitably deal with change. Beginning to search for a dynamic, joint way of seeing or knowing the forest is probably the only hope for encouraging more sustainable forest management generally.

There are a variety of theoretical possibilities for sustainable forest management in the area:

- The Indonesian Government could begin to firmly enforce its forestry regulations (both those pertaining to timber companies and to local communities). In this case the concept of "participation" with which we began this pre-test would be appropriate, since such a policy would probably begin with one-way, directive, "top-down" communication;

- The indigenous system could be acknowledged, legalised and supported by the government - devolution, involving significant gains in access to and responsibility for resources by local people, and significant losses for powerful stakeholders like timber companies; or, more possibly,

- A process of negotiation could be undertaken which would involve recognition of the existing costs and benefits to each stakeholder and co-operative planning for the future ${ }^{22}$. This could involve either a division of benefits/responsibilities/areas or a series of compromises among subsistence, commercial and conservation interests in the area. 
To evaluate the sustainability of forest management in a particular environment, one of our first steps must be to identify who is really managing that forest. Only then can we develop ways to integrate that management with the interests of other stakeholders (e.g., Lewis 1989). In the DSWR case, the participation of the timber concessionaires in the traditional management of local people would definitely be a more sustainable option than persuading the local people to follow in the footsteps of the timber concessionaires.

\section{Summary and Conclusions}

In this short paper, we have presented the results of a pre-test undertaken in West Kalimantan. Two of the four methods initially proposed were found to be useful (with some revision), in concert: the quantitative participatory card sorting method, and the qualitative "Iterative Continuum Method" or ICM.

The research findings from the application of these methods confirmed our suspicion that local people were the primary managers of the forest in the area. This prompted us to rethink our assumptions about the participation of local people in forest management. We realised that we had assumed the pre-eminence of timber concessionaires in forest management - consistent with national laws - with local people potentially participating in the modern system. However, in the pre-test context, traditional forest management appeared far more sustainable and operational than did management by the timber concessionaire.

We then proposed use of Jordan's concept of "authoritative knowledge" to account for the curious dismissal of indigenous systems in contexts like this where local management is so obvious and so widely acknowledged. The modern approach to forest management is, at the moment, generally considered authoritative; the traditional system is not - regardless of evidence to the contrary. This probably should change if we are interested in fostering more sustainable management. The existence of a functioning indigenous management system constitutes a form of social or cultural capital which can serve an important function if recognised and integrated into other management systems.

On the basis of the problems identified with the concept of "participation in forest management", we concluded that it may be useful, within the context of criteria and indicators, to try to break the concept down into its constituent parts. One issue that seemed appropriate in DSWR was local people's "rights and obligations to manage the forest co-operatively" (see also - Drijver 1992). The definition of who has which rights and obligations may need to be assessed for each forest management unit, and defined locally.

One of our goals in the CIFOR project is to develop simple, transparent, inexpensive methods, or tools, for use in assessing sustainable forest management. The methods reported in this paper represent a start. But as we continue to pursue this goal, with regard to the idea called "people's participation in forest management", several additional issues may be important:

- the determination of how "good" for forests and people the various local management systems are: for instance, the conversion of East Kalimantan's natural forests to industrial timber plantations - a very "modern" change - is well under way; yet this land use is obviously not compatible with maintaining the previous biodiversity or the many functions the natural forests has provided for local inhabitants.

- what values are held by different stakeholders (some being more conducive to sustainable forest management than others): For instance, in some parts of Brazil, there are Indios (hunter gatherers who had a very extensive, non-intrusive management system which did not produce a significant surplus); there are Ribereiño's (river-dwelling peoples, who have a less extensive, more intrusive, and more productive shifting cultivation system); there are government and timber company officials and Colonos (or settlers), who would prefer to cut the forest down, either to secure the timber or to convert it to pasture and agricultural lands, thus producing something completely new. The implications of such different approaches for participation in forest management must be examined further.

- and how productive of forest products each sys tern is and can be. The determination of this issue is complicated by the fact that assessors, depending on their orientation, tend to evaluate productivity on the basis of one or two products, whereas natural forests are likely, in fact, to have many products. The usefulness of various forest products also depends on the needs and knowledge of the various users.

In sum we are convinced that co-operation and mutual accommodation will be necessary among the various stakeholders connected with natural forests if they are to survive and be managed sustainably for all concerned. We hope this discussion can move us a little further forward in developing appropriate and useful tools for assessing the social dimensions of sustainable forest management. 


\section{End Notes}

1. Colfer is a Principal Scientist at CIFOR and Wadley is a doctoral candidate in Anthropology at Arizona State University and a CIFOR consultant. Other team members whose assistance has been highly valued include Ravi Prabhu (project director, CIFOR), Sahardi (Agency for the Conservation of Natural Resources, DSWR; and resident of Ng. Kedebu'), Ida Marlia (periodic resident of Cincin, Lawa and Bukit Rancong, DSWR), Gideon Elong, Yustina Lenjai and Dana Atam (residents of Wong Garai), Lasah, Tamin and Ajo' (residents of Kelayang) and Emily Harwell (Doctoral student at Yale University working in Kelayang). The co-operation and assistance of so many stakeholders in and around DSWR is most gratefully appreciated. Thanks are also due to Eva Wollenberg, Nicolette Burford de Oliveira and Esther Katz for their constructive comments on earlier drafts. The financial and administrative support of CIFOR, Wetlands International - Indonesia Programme, PHPA, and KSDA are gratefully acknowledged, as well as the informal co-operation of members of the ODA team at DSWR. The help of the people in the Lakes area has been the most critical. We thank them for their patience and good humour during our pre-test.

2. During the project's first year (1994-95), five interdisciplinary field teams were assembled, to test five existing sets of criteria and indicators in five locations in Africa, Asia, Europe and Latin America (see Prabhu et al. 1996, for a full description of our results; also Colfer 1995; Colfer et al. 1995; Namkoong et al. 1996; Prabhu and Colfer 1996; Wollenberg and Colfer 1996). These criteria and indicators - from Rainforest Alliance in the US, Lembaga Ekolabel Indonesia, GTW in Germany, the Soil Association in the UK, and DDB in the Netherlands - were initially developed for use in certification of timber from sustainably managed forests. During the course of the five field trials above, three major issues, pertaining to social conditions, emerged which were identified as important by all the teams. These were security of inter-generational access to resources and sharing of benefits, participation in forest management by all stakeholders, and a reasonably low level of conflict.

3. During the course of the same pre-tests and tests, we anticipate looking at causal links and methods pertaining to inter-generational access to resources and conflict. and sustainable forest management.

4. Pseudonyms have been created for the communities and timber concessions in and around Danau Sentarum Wildlife Reserve to protect the privacy of individuals who have shared their perspectives.

5. Sahardi from KSDA and Ng. Kedebu'; Ida Marlia from Cincin and Lawah; Gideon Elong, Yustina Lenjai and Dana Atam from Wong Garai; Lasah, Tamin and Ajo' from Kelayang; and Emily Harwell, a doctoral student from Yale University's School of Forestry and Environmental Studies.

6. 100-300 inhabitants each.

7. de Oliveira, for instance, emphasises the importance of community organisation as a means of enhancing local communities' participation in management efforts of other stakeholders (pers. comm. 1996).

8. For clarity we quote two foresters' views of forest management is: Davis and Johnson (1987: 1) say "Forest management involves the use of forests to meet the objectives of landowners and society." Lowe (1995: 343) states that "Forest management constitutes the ways and means of achieving the objectives of conservation and development of forests." One can imagine some conflict arising from these definitions, depending on the differing needs and objectives of local, national and international stakeholders.

9. Locally relevant colours were selected as far as possible to simplify the interview process for those who could not or could barely read. Blue for local community (fishers), gold for government (the colour of the dominant party), green for the conservation project, etc.

10.These questions were developed in the field under rather ad hoc conditions. Although "not bad", we think they can be improved in future iterations. We particularly welcome comments on their relevance to forest management, from the perspectives of foresters.

11.When needed, this was further explained as involving "rights" or "status" in forest management. 
12. The exact number of respondents cannot be given, because of our use of groups in some cases, but there were at least 44 individual villagers queried; and at least 17 outsiders. There were also several traders whose insider-outsider status is ambiguous

13. This method was also used with continua on "intergenerational access to resources" and "conflict's effect on sustainability". Use of these other continua also involved the development of anchoring "steps" toward sustainability.

14. During the course of the project on criteria and indicators, Colfer encountered strong resistance from at least two European social scientists (Bo Ohlsson and Jan Kressin) to the term, participation. Both felt it was a patronising concept. The conclusions of this field research support their views, which Colfer resisted previously.

15. No special criticism is intended for these authors; rather they are simply used to illustrate an assumption which is very widely held, and probably warranted, in many contexts. Our point is simply that it is not warranted in all cases.

16. In Colfer et al. (1995) and Wollenberg and Colfer (1996), we outline our perspective that sustainable forest management includes the well-being of the people in the forest.

17. As distinct from "conflicts" which of course always abound. See the Proceedings from FAO's E-Mail Conference on Conflict and Community Forestry, January March 1996, for a thorough and fascinating series of papers and discussions on this issue.

18. In the American, high-tech, birth context, she found that certain knowledge counts ("authoritative knowledge" ) and other knowledge does not. She used examples of childbirth in Mexico and the US, for instance, to demonstrate the difference. In the US childbirth context, authoritative knowledge is (or was at that time) held exclusively by medical personnel. The birthing mother's knowledge (for instance of her bodily functions) is ignored and trivialised. In Mexico, a birth attendant works closely with the birthing mother, acknowledging both the mother's and the birth attendant's authoritative knowledge about what is occurring. Jordan provides evidence of this, both from participant observation and from videotaping of births in both contexts.
19. "Structural superiority" is closely connected to the "power deficit" we have proposed as a dimension in determining who should "count" in sustainable forest management at the forest management unit level (Colfer 1995).

20. Dudley (1996b) has taken the eight design principles for collective management of a common property resource compiled by Ostrom (1990), and evaluated their fit with conditions in the DSWR area (Appendix F; see also Hobley and Shah 1996, for an examination of many of the same issues). His conclusions focus on fisheries, but they illustrate the extent of indigenous natural resource management in the Reserve.

21. Cf. Fox's (1996) comment about community resource management, which he says "...is a process; it will never be finished; there is no single solution; and conflict cannot be escaped, it is part of the process."

22. Cf. Behan's (1988) note that “'Participative' public involvement...is a democratic, personalized, dynamic, interactive process of bargaining, negotiation, mediation, and give-and-take among and between the constituents and managers alike....Public involvement becomes a continuous process, no longer a series of discrete events." 


\section{Bibliography}

Ascher, W. 1993. Political Economy and Problematic Forestry Policies in Indonesia: Obstacles to Incorporating Sound Economics and Science. Center for Tropical Conservation, Duke University, Durham, North Carolina.

Bailey, C. and C. Zerner.1992. Local management of fisheries resources in Indonesia: opportunities and constraints. In R. Pollnac, C. Bailey and Alie Poernomo (eds), Contributions to Fishery Development Policy in Indonesia, pp. 38-56. CRIFI Publication, Jakarta.

Bailey, C., R. Pollnac and S. Malvestuto. 1990. The Kapuas River fishery: problems and- opportunities for local resource management. Paper presented at the International Association for the Study of Common Property, Duke University (27-30 September).

Barbier, E.B., J.C. Burgess and C. Folke. 1994. Paradise Lost? The Ecological Economics of Biodiversity. Earthscan Publications Ltd, London.

Behan, R. W. 1988. A plea for constituency-based management. American Forests (July/August): 46-48.

Berkes, F. and C. Folke. 1994. Investing in cultural capital for a sustainable use of natural capital. In A.M. Jansson, M. Hammer, C. Folke and R. Costanaza (eds), Investing in Natural Capital: The Ecological Economics Approach to Sustainability. Island Press, Washington, DC.

Biodiversity Conservation Network (BCN). 1996. Studying the Social Dimensions of Biodiversity Conservation: Strategies, Approaches, Methods and Resources. Document in process. IUCN, Gland.

Carter, J., M. Stockdale, F. Sanchez Roman and A. Lawrence 1995. Local people's participation in forest resource assessment: an analysis of recent experience, with case studies from Indonesia and Mexico. Commonwealth Forestry Review 74:333-342

Chambers, R. 1994. Foreword. In I. Scoones and J. Thompson (eds), Beyond Farmer First: Rural People 's Knowledge, Agricultural Research and Extension Practice, pp. xiii-xvi. Intermediate Technology Publications Ltd, London.

Coakes, S. 1996. The social aspect: participation of stakeholders in forest management. Paper presented at the International Conference on Certification and Labeling of Products from Sustainably Managed Forests, Brisbane, Australia, 26-31 May.

Clay, J.W. 1988. Indigenous Peoples and Tropical Forests. Cultural Survival, Inc., Cambridge, Mass.

Coleman, J.S. 1988. Social capital in the creation of human capital. American Journal of Sociology 94: S95S120.

Colfer, C.J.P. 1983. On communication among 'unequals.' International Journal of Intercultural Communication 7: 263-283.

Colfer, C.J.P. 1995. Who Counts Most in Sustainable Forest Management? CIFOR Working Paper No. 7, Bogor, Indonesia.

Colfer, C.J.P. with R.G. Dudley. 1993. Shifting Cultivators of Indonesia: Managers or Marauders of the Forest? FAO Community Forestry Case Study No. 6, Rome.

Colfer, C.J.P. with R. Prabhu and E. Wollenberg. 1995. Principles, Criteria and Indicators: Applying Ockham 's Razor to the People-Forestry Link. CIFOR Working Paper No. 8, Bogor, Indonesia..

Colfer, C.J.P. with N. Peluso and Chin See Chung. (in press). Beyond Slash and Burn: Lessons from the Kenyah on Managing Borneo's Rain Forests. New York Botanical Gardens Press, New York.

Colfer, C.J.P., R.L. Wadley and Enis Widjanarti. 1996. Using indigenous organizations from West Kalimantan. In P. Blunt and D.M. Warren (eds), Indigenous Organizations and Development, pp. 228-238. Intermediate Technology Publications, Inc., London.

Davis, L.S. and K.N.Johnson. 1987. Forest Management, Third edition. McGraw Hill, New York.

Davis-Floyd, R. and C. Sargent (eds). (in press). Childbirth and Authoritative Knowledge: Cross-Cultural Perspectives. University of California Press, Berkeley.

Drijver, C.A. 1992. People's participation in environmental projects. In E. Cross and D. Parkin (eds), Bush Base: Forest Farm: Culture, Environment and Development, pp. 131- 145. Routledge, London.

Dudley, R.G. 1996a. The Fishery of the Danau Sentarum Wildlife Reserve, West Kalimantan, Indonesia: Fishery Analysis. Report to Wetlands International, Bogor, Indonesia.

Dudley, R.G. 1996b. The Fishery of the Danau Sentarum Wildlife Reserve, West Kalimantan, Indonesia: Management Considerations. Report to Wetlands International, Bogor, Indonesia. 
Dudley, R.G. and C.J.P. Colfer. 1993. Conservation Sub-Project Quarterly Report and Attachments (June). Asian Wetlands Bureau, Bogor, Indonesia.

Fortmann, L. and J.W. Bruce (eds). 1988. Whose Trees? Proprietary Dimensions of Forestry. Westview Press, Boulder, Colorado.

Fox, J. 1996. Response to Cabarle and Lynch's paper on "Conflict and community Forestry: Legal Issues and Responses". FAO e-mail Conference, January-March. (11 March)

Giesen, W. 1987. Danau Sentarum Wildlife Reserve: Inventory, Ecology and Management Guidelines. WWF and PHPA, Bogor, Indonesia.

Head, S. and R. Heinzman (eds). 1990 Lessons of the Rainforest. Sierra Club, San Francisco.

Hobley, M. and K. Shah. 1996. What makes a local organisation robust? Evidence from India and Nepal. ODI Natural Resource Perspectives No. 11 (July): 1-6.

Isham, J., D. Narayan and L. Pritchett. 1995 Does participation improve performance? Establishing causality with subjective data. The World Bank Economic Review 9: 175-200.

Jordan, B. 1991. Technology and Social Interaction: Notes on the Achievement of Authoritative Knowledge in Complex Settings. Institute for Research on Learning and Work Practice and Technology System Sciences Laboratory, Xerox Palo Alto Research Center, Palo Alto, California.

Jordan, B. (in press). Authoritative knowledge and its construction. In R. Davis-Floyd and C. Sargent (eds), Childbirth and Authoritative Knowledge: Cross-Cultural Perspectives. University of California Press, Berkeley.

Jordan, B. with R. Davis-Floyd. 1993. Birth in Four Cultures: A Cross-cultural Investigation of Childbirth in Yucatan, Holland Sweden and the United States. Waveland Press, Prospect Heights, Ill.

Lewis, H.T. 1989. Ecological and technological knowledge of fire: Aborigines versus park rangers in northern Australia. American Anthropologist 91: 940-961.

Long, N. and M. Villareal. 1994. The interweaving of knowledge and power in development interfaces. In I. Scoones and J. Thompson (eds), Beyond Farmer First: Rural People's Knowledge, Agricultural Research and Extension Practice, pp. 41-51. Intermediate Technology Publications Ltd, London.

Lowe, P.D. 1996. The Limits to the Use of Criteria and Indicators for Sustainable Forest Management. Commonwealth Forestry Review 74: 343-349.

Malvestuto, S. 1989. Research and Development Strategies for the Kapuas River Fishery in West Kalimantan, Indonesia: A Project Proposal. Submitted to USAID-Jakarta.

Namkoong, G., T. Boyle, H.-R. Gregorius, H. Joly, 0. Savolainen, W. Ratnam and A. Young. 1996. Testing Criteria and Indicators for Assessing the Sustainability of Forest Management: Genetic Criteria and Indicators. CIFOR Working Paper No. 10, Bogor, Indonesia.

Ostrom, E. 1990. Governing the Commons. The Evolution of Institutions for Collective Action. Oxford University Press, Melbourne, Australia.

Ostrom, E. 1994. Neither Market nor State: Governance of Common-Pool Resources in the Twenty-first Century. International Food Policy Research Institute, Washington, DC.

Peluso, N. 1994. The Impact of Social and Environmental Change on Forest Management. FAO Community Forestry Case Study Series No. 8, Rome.

Peters, C. 1993. Forest Resources of the Danau Sentarum Wildlife Reserve: Observations on the Ecology, Use and Management Potential of Timber and Non-timber Products. Field Report I to Asian Wetland Bureau, Bogor, Indonesia.

Peters, C. 1994. Forest Resources of the Danau Sentarum Wildlife Reserve: Strategies for the Sustainable Exploitation of Timber and Non-timber Products. Field Report II to Asian Wetland Bureau, Bogor, Indonesia.

Pimbert, M.P. and J.N. Pretty. 1995. Parks, People and Professionals: Putting "Participation" into Protected Area Management. UNRISD, IIED, and WWF-International (Discussion Paper), Geneva.

Prabhu, R., C.J.P. Colfer, P. Venkateswarlu, Lay Cheng Tan, Rinekso Soekmadi and L. Wollenberg. 1996. Testing Criteria and Indicators for the Sustainable Management of Forests. Phase I Final Report. CIFOR Special Publication, Bogor, Indonesia.

Putnam, R.D. 1993. The prosperous community: social capital and public life. The American Prospect 13: 35-42.

Redford, K.H. and C. Padoch (eds). 1992. Conservation of Neotropical Forests: Working from Traditional Resource Use. Columbia University Press, New York.

Salas, M. 1994. 'The technicians only believe in science and cannot read the sky': the cultural dimension of the knowledge conflict in the Andes. In I. Scoones and J. Thompson (eds), Beyond Farmer First: Rural People 's Knowledge, Agricultural Research and Extension Practice, pp. 57-59. Intermediate Technology Publications Ltd, London. 
Songan P. 1993. A naturalistic inquiry into participation of the Iban peasants in the Land Development Project in the Kalaka and Saribas Districts, Sarawak, Malaysia. Borneo Research Bulletin 25: 101-121.

Umans, L. 1995. Meaning and practice of participation: the case of Nepal. (Forestry and People in South-East Asia). BOS NiE uWSLETTER 32(3): 42-50.

Wadley, R.L. 1996. Variation and changing tradition in Iban land tenure. Borneo Research Bulletin 27: in press.

Wadley, R.L., C.J.P. Colfer and I. Hood (1997). Hunting and natural resource management among forest farmers in Indonesian Borneo: a comparison of non-human primates and other large mammals. Human Ecology 27: in press.

Wickham, T. 1996. Community-Based Participation in Wetland Conservation: Activities and Challenges of the Danau Sentarum Wildlife Reserve Conservation Project, Danau Sentarum Wildlife Reserve, West Kalimantan, Indonesia. Report to Wetlands International, Bogor, Indonesia.

Wollenberg, E. and C.J.P. Colfer. 1996. Social sustainability in the forest: a progress report of a project aiming to test criteria and indicators for the social dimensions of sustainable forest management? Tropical Forest Update 6(2): 9-1 1.

World Bank. 1994. World Bank Sourcebook on Participation (December). (Draft for comment and use.) Environment Department, Washington, DC (1996 version now available). 


\section{Appendix A - Iterative Continuum Method}

The "iterative continuum" method requires recording observations on at least 14 field days. On the final day of observations, specify the following regarding each continuum:

- Your "best guess" for placement, direction and speed of change, on each continuum. For speed of change, use red if fast, yellow if intermediate, and green if slow/stable.

- A listing of the causal links identified among factors on the continuum and sustainable forest management.

- How great is the variation over the days of observations, and how should this variation be interpreted?

- Your qualitative evaluation of the utility, difficulty and reliability of this method - cost effectiveness.

Participation in forest management [revised to say "Rights and obligations to manage the forest co-operatively"]

significant insignificant

[space available here]

Consider at least women's and men's roles in monitoring compliance with regulations, conflict resolution, incorporation of indigenous knowledge and control over direction and speed of social change. 


\section{Appendix B -Steps Involved in Participatory Card Sorting Exercise}

1. Determine significant stakeholders. [We identified 6]

2. Write stakeholder categories on cards of varying colours (with local significance if possible, to simplify the task for the illiterate or marginally literate).

3. Select locally relevant topics/questions such as forest products which are collected, used, managed, and disputed; and/or stakeholders among whom conflicts abound. Issues pertaining to knowledge, regulations, conflict resolution and sanctions are particularly important. [These serve as a proxy for the more abstract "forest use" or "forest management." We asked about looking for information on fish, looking for rattan, looking for valuable wood and problems between timber companies and other parties.]

4. In selecting potential respondents, try to represent males and females equally; select people of varying ages; conduct 12- 15 interviews under the varying human conditions that exist at the FMU. [We selected two ethnic groups in four locations, plus larger towns along the Kapuas.]

5. For each topic/question, have the respondent(s) perform two tasks: important.

a) Order all the stakeholders/cards, by importance (rights, status, role) with 1 most

b) Allocate 100 points among the stakeholders/cards, according to frequency of interaction. Zero is an acceptable number of points.

6. Collect information for each interview on at least location, date, interviewer, and respondents' age, sex and work. Interviews can be single or group.

7. Calculate the mean score for the four questions, for each stakeholder, first from column A, "importance," and then separately from column B, "frequency of interaction".

8. Disaggregate the responses as desired. (We first separated by village, and by sex, within the Reserve; then by occupation along the Kapuas.) Separate tables can be made, for instance, for separate areas, with columns for males, females and mixed groups.

9. Once the appropriate groups of respondents have been determined and separated, average scores (from all the relevant respondents) for the importance of each stakeholder and the frequency of interaction with each stakeholder can be computed. In computing the overall average score for a particular sub-sample (e.g., a village), be sure to return to the total subsample data set, since the numbers in each category may vary.

10. Those stakeholders with low scores in Column A (importance) are perceived locally to play an important role in forest management. Those stakeholders with low scores in Column B (frequency of interaction) are marginally or not involved in day to day forest management. 


\title{
Card Sorting Exercise
}

\author{
Village \\ Interviewer \\ Date
}

A. Who is most important if you are looking for information about fish?

(l=most important, $2=2$ nd most important, and so on until 6)

B. Divide 100\% among the six groups below according to frequency of (how often) interaction.

\begin{tabular}{llll} 
Groups & Colour & $\begin{array}{c}\text { Importance } \\
(1-6)\end{array}$ & Value (from 100) \\
\hline Local Community & blue & & \\
Other community & brown & & \\
Government & yellow & & \\
Concesionaire & red & & $100 \%$ \\
Conservation Project & green & & \\
Traders & dark yellow & &
\end{tabular}

A, Who is most important when you want to find rattan?

(l=most important, $2=2$ nd most important, and so on until 6)

B. Divide $100 \%$ among the six groups below according to frequency of (how often) interaction.

\begin{tabular}{|c|c|c|c|}
\hline Groups & Colour & $\begin{array}{l}\text { Importance } \\
(1-6)\end{array}$ & Value (from 100) \\
\hline
\end{tabular}

\begin{tabular}{ll}
\hline Local Community & blue \\
Other community & brown \\
Government & yellow \\
Concesionaire & red \\
Conservation Project & green \\
Traders & dark yellow
\end{tabular}


A. Who is most important if you want to find tembesu' or other valuable wood?

(l=most important, $2=2$ nd most important, and so on until 6 )

B. Divide 100\% among the six groups below according to frequency of (how often) interaction.

\begin{tabular}{|c|c|c|c|}
\hline Groups & Colour & $\begin{array}{l}\text { Importance } \\
(1-6)\end{array}$ & Value (from 100) \\
\hline Local Community & blue & & \\
\hline Other community & brown & & \\
\hline Government & yellow & & \\
\hline Concesionaire & red & & \\
\hline Conservation Project & green & & \\
\hline \multirow[t]{2}{*}{ Traders } & dark yellow & & \\
\hline & & & $100 \%$ \\
\hline
\end{tabular}

A. Who is most important if you there is a problem with the concessionaire?

(l=most important, $2=2$ nd most important, and so on until 6)

B. Divide $100 \%$ among the six groups below according to frequency of (how often) interaction.

\begin{tabular}{|c|c|c|c|}
\hline Groups & Colour & $\begin{array}{l}\text { Importance } \\
(1-6)\end{array}$ & Value (from 100) \\
\hline
\end{tabular}

Local Community blue

Other community brown

Government yellow

Concesionaire red

Conservation Project green

Traders dark yellow 


\begin{tabular}{|c|c|c|c|c|}
\hline $\begin{array}{l}\text { Mean Order of Importance } \\
\text { Importance }\end{array}$ & $\begin{array}{c}\text { men } \\
(n=5)\end{array}$ & $\begin{array}{c}\text { women } \\
(n=7)\end{array}$ & $\begin{array}{l}\text { mixed } \\
\text { group } \\
(n=4)\end{array}$ & $\begin{array}{c}\text { Overall } \\
\text { Mean }\end{array}$ \\
\hline Community & 1.00 & 1.00 & 1.00 & 1.23 \\
\hline Other Communities & 3.00 & 3.00 & 3.00 & 2.73 \\
\hline Government & 3.00 & 4.00 & 4.00 & 3.53 \\
\hline Traders & 4.00 & 5.00 & 4.00 & 4.48 \\
\hline Timber Companies & 5.00 & 5.00 & 4.00 & 4.52 \\
\hline Conservation Project & 5.00 & 5.00 & 4.00 & 4.92 \\
\hline
\end{tabular}

* Several Danau Seluang respondents did not rank stakeholders they considered unimportant. In those few cases, we ascribed values, in order of appearance on the form.

\begin{tabular}{|lcccc|}
\hline \multicolumn{5}{c|}{ Table 2: Nanga Kedebu' } \\
\hline $\begin{array}{l}\text { Mean Order of } \\
\text { Importance }\end{array}$ & $\begin{array}{c}\text { mixed } \\
\text { men } \\
\text { Importance }\end{array}$ & $\begin{array}{c}\text { women } \\
(\mathrm{n}=7)\end{array}$ & $\begin{array}{c}\text { group } \\
(\mathrm{n}=4)\end{array}$ & $\begin{array}{c}\text { Overall } \\
\text { Imean }\end{array}$ \\
\hline Community & 1.00 & 1.00 & 1.00 & 1.00 \\
Other Communities & 2.96 & 2.14 & 2.63 & 2.57 \\
Conservation Project & 3.75 & 4.43 & 3.94 & 3.75 \\
Government & 3.64 & 3.75 & 3.38 & 3.93 \\
Traders & 4.82 & 4.50 & 4.31 & 4.58 \\
Timber Companies & 4.82 & 5.18 & 5.06 & 5.01 \\
\hline
\end{tabular}

\begin{tabular}{|lcccc|}
\hline \multicolumn{4}{c|}{ Table 3: Northwest of DSWR } \\
\hline $\begin{array}{l}\text { Mean Order of } \\
\text { Importance }\end{array}$ & $\begin{array}{c}\text { Pulau } \\
\text { Duri'* } \\
\text { Importance }\end{array}$ & $\begin{array}{c}\text { Militer } \\
\text { Log Camp } \\
(\mathrm{n}=5)\end{array}$ & $\begin{array}{c}\text { Bemban } \\
(\mathrm{n}=2)\end{array}$ & $\begin{array}{c}\text { Overall } \\
\text { Mean }\end{array}$ \\
\hline Community & 1.95 & 1.06 & 3.63 & 1.93 \\
Other Communities & 3.40 & 3.06 & 3.13 & 3.23 \\
Government & 3.10 & 4.31 & 2.13 & 3.36 \\
Timber Companies & 4.25 & 4.13 & 3.63 & 4.09 \\
Traders & 4.00 & 4.25 & 4.13 & 4.11 \\
Conservation Project & 4.30 & 4.19 & 4.38 & 4.27 \\
\hline
\end{tabular}

'Pulau Duri' is a larger Melayu village; Bemban is officially part of Pulau Duri' but it's inhabitants are Iban, and largely manage their own affairs. 


\begin{tabular}{|lcccc|}
\hline \multicolumn{5}{c}{ Table 4: Kapuas } \\
\hline Mean order of importance & $\begin{array}{c}\text { Cincin } \\
\text { Women } \\
\text { Importance }\end{array}$ & $\begin{array}{c}\text { Business } \\
(\mathrm{n}=2)^{*}\end{array}$ & $\begin{array}{c}\text { Gov't } \\
(\mathrm{n}=7)\end{array}$ & $\begin{array}{c}\text { Overall } \\
\text { Mean }\end{array}$ \\
\hline Community & 2.38 & 1.67 & 1.68 & 1.77 \\
Government & 3.50 & 2.96 & 2.54 & 2.83 \\
Other Communities & 3.75 & 3.50 & 4.29 & 3.90 \\
Traders & 4.50 & 3.54 & 4.36 & 3.90 \\
Timber Companies & 2.88 & 4.42 & 4.04 & 4.07 \\
Conservation Project & 4.13 & 4.92 & 4.11 & 4.55 \\
\hline
\end{tabular}

*These two groups were composed of about six women total.

\begin{tabular}{|lccc|}
\hline \multicolumn{3}{c|}{ Table 5: Kelayang } \\
\hline $\begin{array}{l}\text { Mean Order of } \\
\text { Importance }\end{array}$ & $\begin{array}{c}\text { Women } \\
(\mathrm{n}=6)\end{array}$ & $\begin{array}{c}\text { Men }^{*} \\
(\mathrm{n}=8)\end{array}$ & $\begin{array}{c}\text { Overall } \\
\text { Mean }\end{array}$ \\
\hline Importance & 1.54 & 2.19 & 1.91 \\
\hline Community & 2.96 & 2.28 & 2.57 \\
Other Communities & 3.33 & 3.09 & 3.20 \\
Timber Companies & 4.33 & 3.97 & 4.13 \\
Traders & 4.33 & 4.44 & 4.39 \\
Government & 4.71 & 4.78 & 4.75 \\
Conservation Project & & & \\
\hline
\end{tabular}

*The assistant conducting this survey neglected to indicate whether the interviews were individual or in groups.

\begin{tabular}{|lcccc|}
\hline \multicolumn{5}{c|}{ Table 6: Danau Seluang } \\
\hline Mean Frequency of Interaction & $\begin{array}{c}\text { men } \\
(\mathrm{n}=5)\end{array}$ & $\begin{array}{c}\text { women } \\
(\mathrm{n}=7)\end{array}$ & $\begin{array}{c}\text { mixed } \\
\text { group } \\
(\mathrm{n}=4)\end{array}$ & $\begin{array}{c}\text { Overall } \\
\text { Frequency }\end{array}$ \\
\hline Community & $\%$ & $\%$ & $\%$ & $\%$ \\
Other Communities & 48 & 40 & 45 & 45 \\
Government & 20 & 21 & 16 & 19 \\
Traders & 11 & 7 & 10 & 13 \\
Timber Companies & 11 & 15 & 11 & 10 \\
Conservation Project & 8 & 10 & 10 & 7 \\
\hline
\end{tabular}




\begin{tabular}{|lcccc|}
\hline \multicolumn{5}{c|}{ Table 7: Nanga Kedebu' } \\
\hline Mean Frequency of Interaction & $\begin{array}{c}\text { men } \\
\text { Frequency }\end{array}$ & $\begin{array}{c}\text { women } \\
(\mathrm{n}=7)\end{array}$ & $\begin{array}{c}\text { mixed } \\
\text { group } \\
(\mathrm{n}=4)\end{array}$ & $\begin{array}{c}\text { Overall } \\
\text { mean }\end{array}$ \\
\hline Community & $\%$ & $\%$ & $\%$ & $\%$ \\
Other Communities & 45 & 46 & 53 & 47 \\
Government & 16 & 18 & 16 & 17 \\
Conservation Project & 14 & 12 & 9 & 12 \\
Traders & 14 & 11 & 10 & 12 \\
Timber Companies & 6 & 6 & 8 & 7 \\
\hline
\end{tabular}

\begin{tabular}{|lcccc|}
\hline \multicolumn{7}{|c|}{ Table 8: Northwest of DSWR } \\
\hline $\begin{array}{l}\text { Mean Frequency of } \\
\text { Interaction }\end{array}$ & $\begin{array}{c}\text { Pulau } \\
\text { Duri'* } \\
(\mathrm{n}=5)\end{array}$ & $\begin{array}{c}\text { Militer } \\
\text { log Camp } \\
(\mathrm{n}=4)\end{array}$ & $\begin{array}{c}\text { Bemban } \\
(\mathrm{n}=2)\end{array}$ & $\begin{array}{c}\text { Overall } \\
\text { Mean }\end{array}$ \\
\hline Frequency & 44 & 60 & 43 & 49 \\
\hline Community & 12 & 6 & 17 & 11 \\
Other Communities & 13 & 10 & 10 & 11 \\
Government & 13 & 12 & 6 & 11 \\
Timber Companies & 11 & 6 & 12 & 9 \\
Traders & 8 & 6 & 12 & 8 \\
Conservation Project & & & & \\
\hline
\end{tabular}

Table 9: Kapuas

Mean Frequency of Interaction

\begin{tabular}{|lcccc|} 
Frequency & $\begin{array}{c}\text { Cincin } \\
\text { Women } \\
(\mathrm{n}=2)^{*}\end{array}$ & $\begin{array}{c}\text { Business } \\
(\mathrm{n}=6)\end{array}$ & $\begin{array}{c}\text { Gov't } \\
(\mathrm{n}=7)\end{array}$ & $\begin{array}{c}\text { Overall } \\
\text { mean }\end{array}$ \\
\hline Community & 40 & 40 & 31 & 36 \\
Traders & 17 & 19 & 10 & 15 \\
Government & 12 & 12 & 16 & 14 \\
Timber Companies & 21 & 12 & 10 & 12 \\
Other Communities & 9 & 12 & 8 & 10 \\
Conservation Project & 2 & 4 & 6 & 5 \\
\hline
\end{tabular}

\begin{tabular}{|lccc|}
\hline \multicolumn{4}{|c|}{ Table 10: Kelayang } \\
\hline Mean Frequency of Interaction \\
Fomen \\
Frequency & $(\mathrm{n}=6)$ & $\begin{array}{c}\text { Mean } \\
(\mathrm{n}=8)\end{array}$ & $\begin{array}{c}\text { Overall } \\
\text { Mean }\end{array}$ \\
\hline Timber Companies & 29 & 27 & 28 \\
Community & 25 & 24 & 25 \\
Traders & 15 & 20 & 18 \\
Other Communities & 17 & 17 & 17 \\
Government & 9 & 8 & 9 \\
Conservation Project & 4 & 4 & 4 \\
\hline
\end{tabular}




\section{Appendix C - Communication Network Analysis}

\section{Survey Instrument:}

Date Location Interviewer

Respondent's name Gender Position

Who do you most commonly discuss use of forest products with (e.g., regulations, rights, sanctions)?

$\begin{array}{lll}\text { Name } & \text { Gender } & \text { Position } \\ \text { Name } & \text { Gender } & \text { Position } \\ \text { Name } & \text { Gender } & \text { Position } \\ \text { Name } & \text { Gender } & \text { Position } \\ \text { Name } & \text { Gender Position }\end{array}$

List timber company people whom you know

$\begin{array}{lll}\text { Name } & \text { Gender } & \text { Connection } \\ \text { Name } & \text { Gender } & \text { Connection } \\ \text { Name } & \text { Gender } & \text { Connection } \\ \text { Name } & \text { Gender } & \text { Connection } \\ \text { Name } & \text { Gender } & \text { Connection }\end{array}$

List conservation project people whom you know

$\begin{array}{lll}\text { Name } & \text { Gender } & \text { Connection } \\ \text { Name } & \text { Gender } & \text { Connection } \\ \text { Name } & \text { Gender } & \text { Connection } \\ \text { Name } & \text { Gender } & \text { Connection } \\ \text { Name } & \text { Gender } & \text { Connection }\end{array}$

Who else is important in managing forests in this area?

$\begin{array}{lll}\text { Name } & \text { Gender } & \text { Connection } \\ \text { Name } & \text { Gender } & \text { Connection } \\ \text { Name } & \text { Gender } & \text { Connection } \\ \text { Name } & \text { Gender } & \text { Connection } \\ \text { Name } & \text { Gender } & \text { Connection }\end{array}$


Appendix D - Researcher Guide Pertaining to the Four Proposed Functions of Participation

\section{Reducing non-compliance with regulations}

1. Are people aware of the regulations that timber companies are supposed to follow? (men, women, old, young)

Examples:

[boundaries, allowable cut, minimum diameter, replanting, minimum wages, safety rules, distance from streams, waste, planning requirements]

proposed C\&I:

2. Do local people observe or hear of infractions by the timber companies in the area? (men, women, old, young)

Examples:

[note boundary infractions, note logs that are too small or of the wrong species, wasteful practices, environmentally damaging practices, use of chemicals; knowledge of company plans before implementation]

proposed C\&I:

3. Do people report infractions? (men, women, young, old) To whom?

Examples:

[to village leader, to temenggung, to Forestry officials, to local gov't, to KSDA, to fisheries dept official, to NGOs]

proposed C\&I:

4. Are there predictable sanctions, in case of infractions? By whom?

Examples:

[fine, work stoppage, withdrawal of HPH, payment of damages; by courts, agreement among stakeholders, forestry personnel]

proposed C\&I:

\section{Reducing conflict about forest resources/Converting it to mutual accommodation}

1. What kinds of problems occur between timber companies and local people?

Examples:

[chemicals in water supply, overstepping boundaries, use of sacred sites, adverse effects of outsiders' presence on local culture; effects on fishing/hunting; noise]

proposed C\&I:

2. What kinds of problems occur between timber companies and workers?

Example:

[minimal employment for local people, unsafe working conditions, non-payment of salary/fees] proposed C\&I: 
3. Are problems successfully and satisfactorily resolved? How and how reliably?

Examples:

[courts, negotiations, arbitration; agreement on rights and responsibilities of each stakeholder] proposed C\&I:

\section{[Issues of Voice]}

1. Can local people name the decision makers in the timber company and/or the Conservation Project? (men, women, old, young)

Examples:

[one or two key individuals, many individuals]

proposed C\&I:

2. In what contexts do people from the community interact with key timber company personnel/Conservation Project personnel? Who? How regularly?

Examples:

[formal meetings, frequent chance encounters, neighbours, supply of goods to company, at work as employees]

proposed C\&I:

3. How can local people convey their wishes? (men, women, old, young)

Example:

[formal meetings, delegation to company, HPH Bina Desa, forestry agents] proposed C\&I

4. Are the attitudes of timber personnel conducive to local input?

Examples:

[respect expressed, knowledge of local languages, verbal valuing of input, signs that input was sought, convincing acknowledgement of local men's and women's rights to participate; fear on either side; expressions of appreciation of timber personnel by local people] proposed C\&I:

\section{Controlling the Direction/Speed of Change in Local Forest-based Lifeways}

1. What, connected with the timber company or conservation project, is perceived to adversely affect local lifeways:

Examples:

[in-migration of different ethnic groups (increased inter-ethnic strife, competition), prostitution, marrying out by local women, exposure of youth to alien cultures and new temptations, complete dependence of local economic system on company, loss of economic alternatives, increase in dependence of company, loss of diversity in subsistence base]

proposed C\&I:

2. What mechanisms exist for addressing adverse affects? 
Example:

[regular meetings, receptive personnel at HPH Bina Desa, forestry officials with mandate to address such problems; fair laws and accessible courts]

proposed C\&I:

\section{Providing Knowledge for Use in Forest Management}

1. What indigenous knowledge exists that can be used in forest management?

Examples:

[recognition of local species, knowledge of patterns of growth of local species, understanding of local people's subsistence system and "social capital", experiential awareness of historical environmental trends],

proposed C\&I:

2. How is that knowledge integrated into forest management?

Example:

[local people know company plans (e.g., boundary maps, cutting plans, road building plans); companies have baseline surveys or other indicator of knowledge of local systems; management staff/forestry officials recognise people's rights to benefits and a voice; use of forest products reflects compromise between people's and company's needs (if they conflict)] proposed C\&I: 


\section{Appendix E - First Draft of Stages toward a Sustainability Continuum Regarding:}

\section{Recognised, functioning rights to manage forest resources co-operatively:}

0 - No one has these rights or capabilities, and the forest is not managed at all. [This may be no, or a small, problem for sustainability if a) there are few people, and b) there is vast forest]

1 - National policies contradict good forest management and make it difficult for local people to implement their once operational systems [Brazil?]

2 - National (or colonial) systems have subverted local people's management system (e.g., by denying local people's rights and potential); and the national systems are ineffective [Cote d'Ivoire; Xishuangbana, Southern China; Sanggau, West Kalimantan?]

3 - Local people have a still-functioning management system, but more powerful outsiders come and ignore that system. [with adverse effects on ecosystem and on the traditional management system, proving with each interaction local powerlessness - East Kalimantan, Kenya, Tanzania]

$4-$

5 - Local people have a functioning management system, and there is conflicting input from powerful outsiders working to sustain and strengthen that system and powerful outsiders with a vested interest in ignoring or subverting that system [DSWR; Kakadu National Park, Northern Australia]

$6-$

7 - A full functioning, (semi-?) democratic system, subsumed under a wider national society with greater power, in which mechanisms exist for stakeholders to express and negotiate their wishes [ Tlingit of south-eastern Alaska; Annapuma conservation Area Project, Nepal; Kuna Yala, Panama?]

8 - A fully functioning democratic system, in which mechanisms exist for stakeholders to express and negotiate their wishes, but local people's wishes are given the same weight as those of people across the nation [Bushler Bay,USA; British Columbia?]

9 - A fully functioning traditional system in which only locals are affected [probably doesn't exist, but like Kayan Mentarang, East Kalimantan?]; or a fully functioning democratic system, in which mechanisms exist for all stakeholders to express and negotiate their wishes fairly [Austria? Finland? perhaps only seems fairer because countries are smaller than US??].

10 - 
Appendix F - Matrix showing Ostrom's Eight Principles as they operate in DSWR (Dudley 1996b).

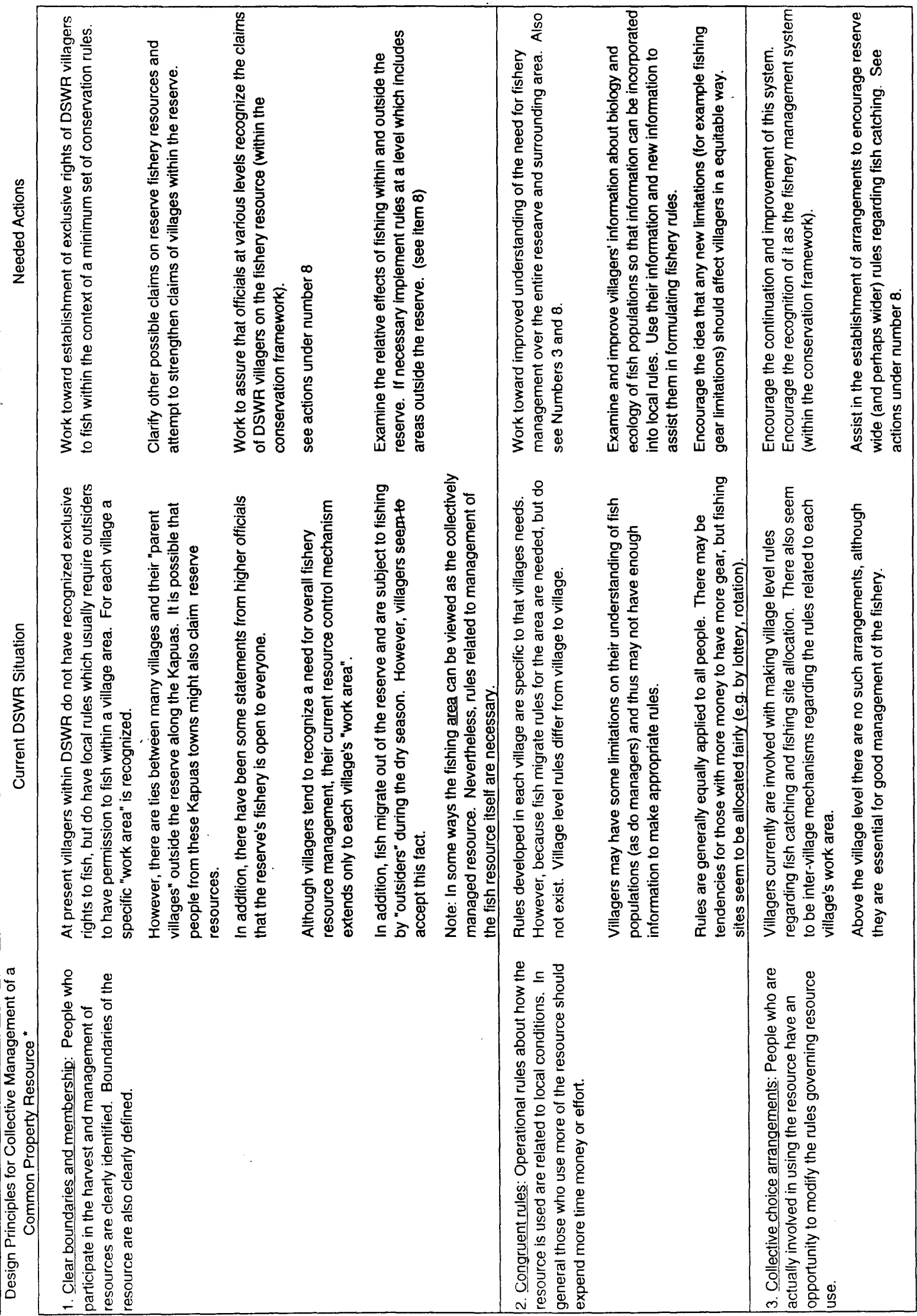




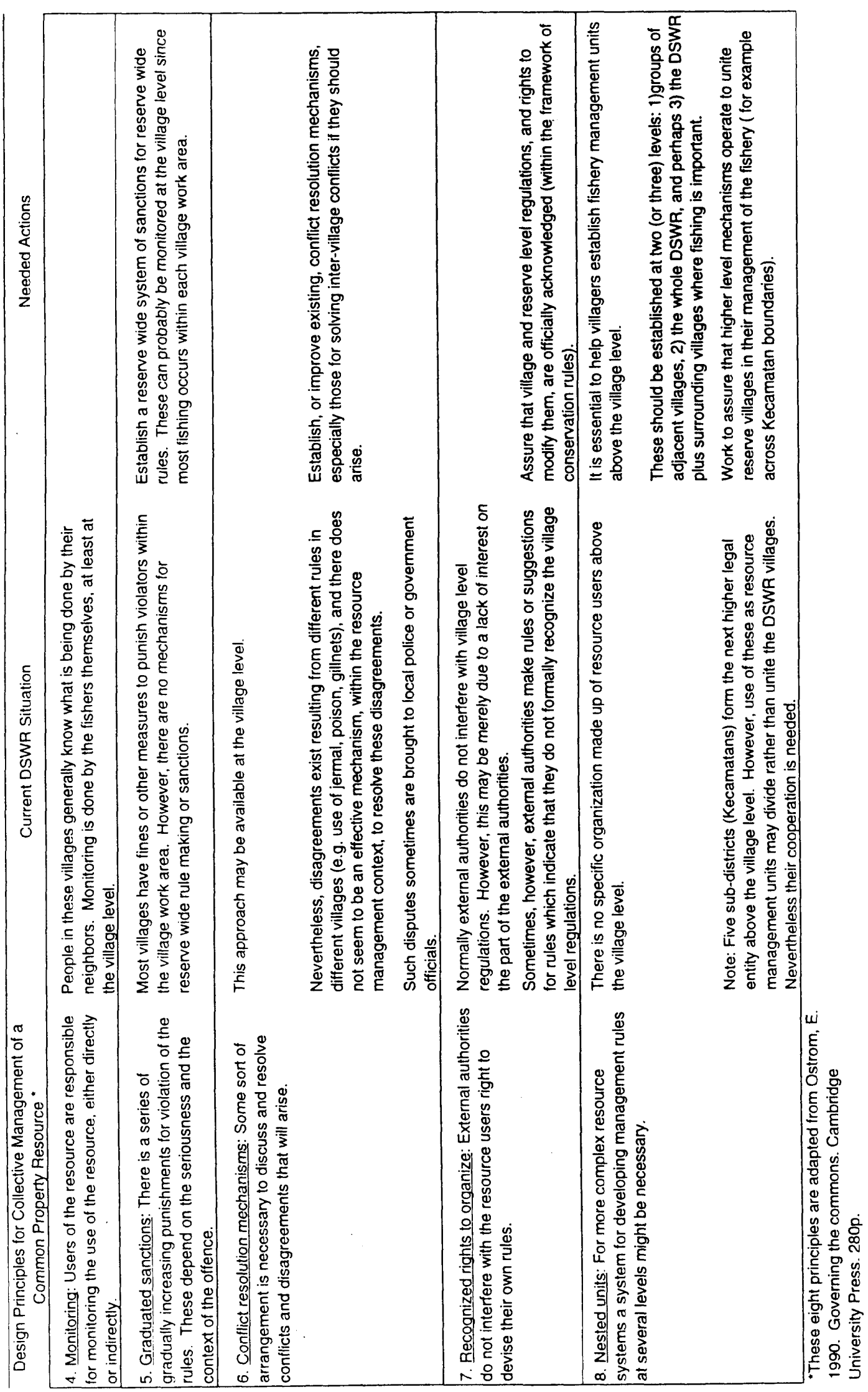




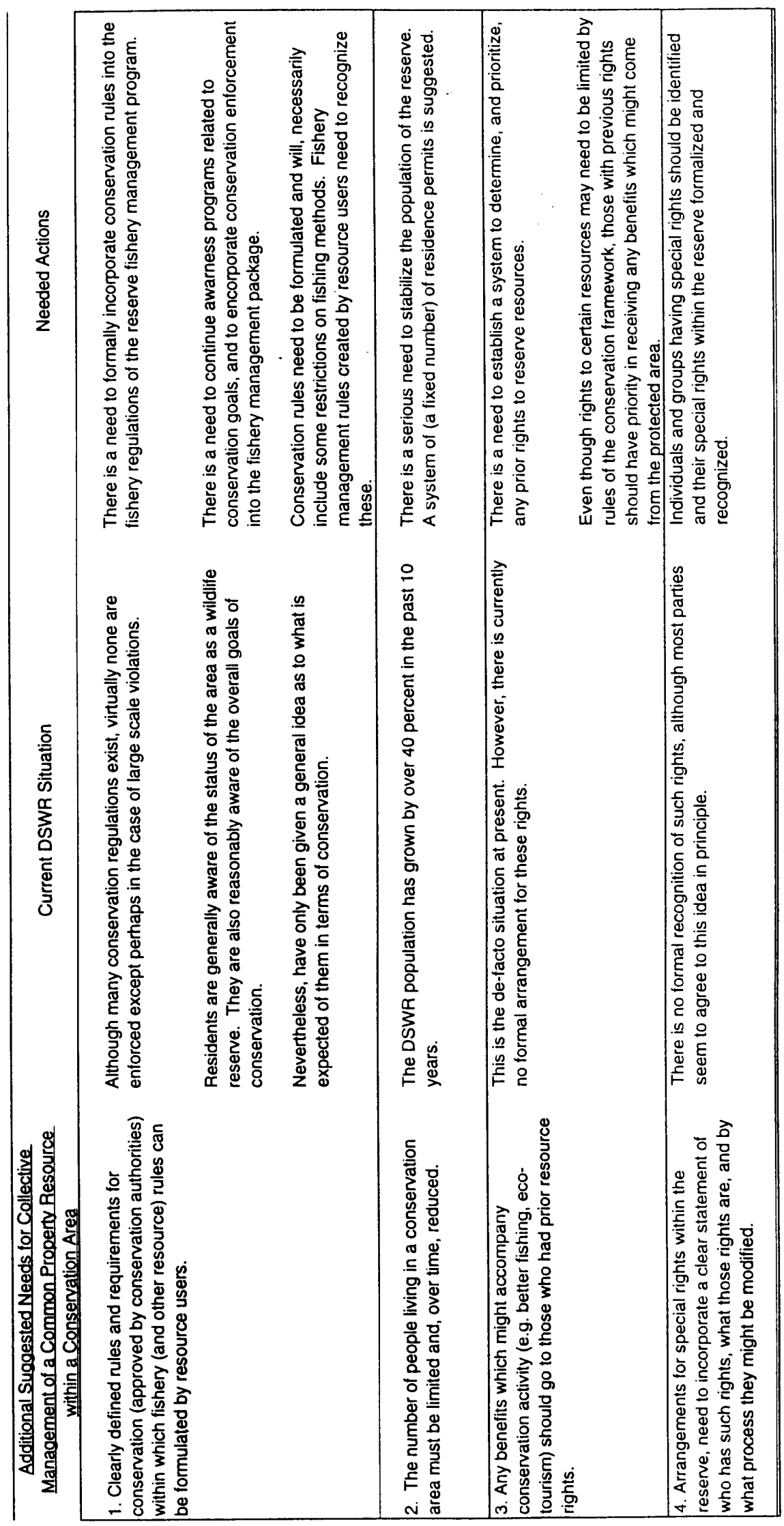

